\title{
Investigation of the Studies on the Use of Scratch Software in Education
}

\begin{tabular}{ccc}
\hline Article Type & Received Date & Accepted Date \\
Research & 22.04 .2019 & 22.05 .2020 \\
\hline
\end{tabular}

\section{Tarık Talan*}

\begin{abstract}
The aim of this study is to classify the methodological tendencies and outputs of the studies conducted on the use of Scratch software in education with their main lines and to examine them in a comprehensive and holistic way. A literature review was conducted based on different databases in line with the purpose of the study and we accessed 76 different studies within this scope. Document review steps were followed to explain the data obtained in the study and to access the necessary concepts and relations. Meta-thematic analyses were performed to complement the data obtained, and qualitative findings were obtained by referring to common codes and themes of qualitative studies. The results of the study indicate that the use of Scratch software in education was found to have positive effects on motivation, self-efficacy, attitude, higher-level thinking, and academic success. In addition, materializing software teaching by freeing it from its abstract and complex structure, enabling students to acquire 21 st-century skills at an early age, encouraging students to trust themselves by boosting their interest and motivation can be defined as some of the positive aspects of the Scratch software. The limitations of the Scratch software were determined as being unsuitable for advanced coding, limited code structure, and difficulty in understanding the logic of some basic structures.
\end{abstract}

Keywords: Programming, coding, Scratch, content analysis.

\footnotetext{
* Corresponding Author: Dr., Gaziantep Islam Science and Technology University, Faculty of Engineering and Natural Sciences, Gaziantep, Turkey. E-mail:ttalan46@hotmail.com, https://orcid.org/0000-0002-5371-4520
} 


\section{Ĕ̆itimde Scratch Yazılımının Kullanımına Yönelik Yapılan Çalışmaların İncelenmesi}

\begin{tabular}{|c|c|c|}
\hline $\begin{array}{l}\text { Makale Türü } \\
\text { Araştırma }\end{array}$ & $\begin{array}{c}\text { Başvuru Tarihi } \\
22.04 .2019 \\
\end{array}$ & $\begin{array}{c}\text { Kabul Tarihi } \\
22.05 .2020\end{array}$ \\
\hline \multicolumn{3}{|c|}{ Tarık Talan ${ }^{* *}$} \\
\hline \multicolumn{3}{|c|}{$\ddot{\mathbf{O z}}$} \\
\hline $\begin{array}{l}\text { Bu çalışmanın amacı, eğ } \\
\text { yöntemsel eğilimleri ve ç } \\
\text { incelenmesidir. Araştırm } \\
\text { taraması yapılmış ve bu } \\
\text { açıklayabilmek, gerekli k } \\
\text { izlenmiştir. Elde edilen } \\
\text { yönlü çalışmaların ortak } \\
\text { Araştırmanın sonuçları eğ } \\
\text { düzey düşünme ve akade } \\
\text { yazılımının programlama } \\
\text { becerilerini erken yaşla } \\
\text { kendilerine güvenmeleri } \\
\text { kodlama yapanlar için } \\
\text { mantığının anlaşılamama }\end{array}$ & $\begin{array}{l}\text { yazılımının kulla } \\
\text { hatlarıyla sınıflandı } \\
\text { uygun olarak farl } \\
\text { arklı çalışmaya ula } \\
\text { kilere ulaşabilmek } \\
\text { nlamak amaçlı me } \\
\text { alarından alıntılar } \\
\text { h yazılımı kullanım } \\
\text { olumlu etkileri old } \\
\text { yut ve karmaşık ya } \\
\text { nası, öğrencilerin } \\
\text { bazı olumlu yönle } \\
\text { ssı, kod yapısının } \\
\text { lımının sınırlılığı ol }\end{array}$ & $\begin{array}{l}\text { lik yapılan çalışmaların } \\
\text { ve bütüncül bir şekilde } \\
\text { arı üzerinden alanyazın } \\
\text { mada elde edilen verileri } \\
\text { man incelemesi adımları } \\
\text { lizler yapıllmış ve nitel } \\
1 \text { bulgulara ulaş1lmıştır. } \\
\text { n, öz-yeterlik, tutum, üst } \\
\text { nektedir. Ayrıca Scratch } \\
\text { somutlaştırması, } 21 \text {. yy } \\
\text { asyonlarını yükselterek } \\
\text { edilebilir. İleri derece } \\
\text { ve bazı temel yapıların } \\
\text { Imiştir. }\end{array}$ \\
\hline
\end{tabular}

Anahtar Sözcükler: Programlama, kodlama, Scratch, içerik analizi.

\footnotetext{
** Sorumlu Yazar: Dr. Tarı TALAN, Gaziantep İslam Bilim ve Teknoloji Üniversitesi, Mühendislik ve Doğa Bilimleri Fakültesi, Gaziantep, Türkiye, E-posta:ttalan46@hotmail.com, https://orcid.org/0000-0002-5371-4520
} 


\section{Introduction}

Most of the students consider classical programming languages, such as Basic or Fortran, as a work that can only be handled by highly trained experts both in terms of visuality and difficulty and complexity of coding (Genç \& Karakuş, 2011). Visual programming languages, such as Visual Basic or $\mathrm{C}++$, are considered very complex to be the first choice. Therefore, the problems experienced in the teaching of programming may have a negative effect on students' attitudes and motivation towards programming (Anastasiadou \& Karakos, 2011; Dinçer, 2018). This, in turn, adversely affects students' success in programming, and many drop the course or the related program (Lahtinen et al., 2005; Kinnunen \& Malmi, 2008). In recent years, user-friendly programming languages, such as Scratch, which are easy to learn, do not require code and are suitable for all ages, have been developed to reduce such negativities and to teach the logic of programming effectively.

Included in many education programs in many countries and used efficiently, Scratch is a free, block-based visual programming application developed with the aim of boosting the programming skills of children. Scratch is a project of the Lifelong Kindergarten Group at the MIT Media Lab in 2003 and it was designed for younger age groups; however, it has become software that can be used by people of all ages (Resnick et al., 2009; Fesakis \& Serafeim, 2009). Although there are studies in the literature claiming that Scratch is more attractive for young age groups (Smith, 2009), some universities, including Harvard and the University of California, use Scratch software in the transition to programming (Resnick et al., 2009). Along with the teaching of Algorithm and Programming, Scratch software is used in various courses, such as Foreign Language, Mathematics, Social Sciences, and Physical Sciences in terms of creating projects with many multimedia items.

Scratch focuses on programming logic and algorithmic thinking rather than a programming language and it works by dragging and dropping visual blocks without the requirement to write codes (Maloney et al., 2010). Unlike traditional programming languages, Scratch allows the users to classify ready-made functions into categories according to their liking and to comprehend the structure of algorithms without using complex structures, such as if and for. In this way, Scratch makes programming more fun and visual, as well as providing game and story design opportunities and renders the process of the algorithm more understandable and frees the problem-solving process from its abstract structure and transforms it into a concrete product (Ramadhan, 2000; Utting et al., 2010; Armoni et al., 2015; Maloney et al., 2010).

Thanks to its advantages, such as not experiencing coding mistakes, including a simple method, such as drag-and-drop, enabling game design, providing instant visual output, and involving not just programming but also design, Scratch considerably contributes to students in the process of introduction to programming training (Şimşek, 2018). While these features render Scratch more accessible to users from different age groups, they also enable them to easily program and easily prepare projects such as interactive stories, visuals, games, animations, simulations, etc., which makes learning more enjoyable (Genç \& Karakuş, 2011; Maloney et al., 2010; Meerbaum-Salant, Armoni \& Ben-Ari, 2013). Individuals can also share these projects that they created with users from all around the world over the "scratch.mit.edu" website (Brennan \& Resnick, 2013; Scratch About, 2019) if they wish. Therefore, members in different parts of the world are able to see these produced projects, learn the coding they are curious about and generate new ideas downloading them to their computers (Adams, 2010).

Scratch has recently been used extensively in the literature and it was found to be effective in providing coding skills to individuals and offering a more memorable, more meaningful and more social environment compared to other programming environments (Maloney et al., 2010). In addition, the studies conducted show that the teaching of programming with Scratch had a significant effect in terms of creativity (Kobsiripat, 2015; Oh, Lee \& Kim, 2013; Taylor, Harlow \& Forret, 2010; Yünkül et al., 2017), that it facilitated mathematical thinking (Brown et al., 2008; Calder, 2010), that it provided a cooperative learning environment (Papatğa, 2016; Taylor, Harlow \& Forret, 2010), that it affected students' self-efficacy perceptions positively (Yükseltürk \& Altıok, 2016a), that it helped students to interact with each other, and that it positively affected their communication (Lopez, Gonzalez \& Cano, 2016; Maloney et al., 2010). 


\section{The Purpose and Significance of the Study}

This study aims to generally classify the methodological tendencies and outputs of the studies regarding the use of Scratch software in education in recent years and to examine them in a comprehensive and holistic way. Conducting such a study is important in terms of rendering Scratch software more qualified and applicable in education as a whole. It is considered that the number of publications related to the use of Scratch software in education has increased rapidly in the related literature, and it has attracted researchers' attention a lot, and hence, current reviews will shed light on the field. Such analyses are especially needed for determining the studies, which will be different from the studies conducted previously in the literature and fulfill the need. It is considered that the results obtained from this research will present a different dimension to the new studies planned to be carried out in the field and will lead the way.

In this study, a comprehensive content analysis was conducted as well as performing a metathematic analysis regarding the subject. This situation differentiates our study from other studies and reveals the originality of the study. With the addition of the meta-thematic dimension, it was ensured that the qualitative views obtained in relation to the subject in the literature, which share a common quality, were combined. Therefore, it is considered that this study will be beneficial for researchers, educators, and students in terms of evaluating the studies published on the use of Scratch software in education according to different criteria regarding its scope. From this point forth, in this study, the studies in the literature were examined and a detailed source was presented to researchers who are interested in using Scratch software in education. Moreover, in this study, information was given about the studies on the subject, and it was aimed to present suggestions to researchers who want to work in this field by determining the less studied or untreated subjects in this field. In accordance with the purpose of study, answers to the following questions were sought:

1. For the studies conducted on the use of Scratch software in education between 2009 and 2019 ,

a. what is the publication type and how are they distributed by years?

b. how are they distributed by teaching stages and numbers?

c. how are they distributed according to the education areas on which they were carried out?

d. how are they distributed according to the experimental application periods?

e. how are they distributed according to research methods?

f. how are they distributed according to data collection tools?

g. how are they distributed according to data analysis methods?

h. how are they distributed according to the variables (study results) examined?

i. how are they distributed by keywords?

2. What are the positive and negative aspects of Scratch software in education within the scope of thematic examination based on document analysis?

\section{Method}

In this study, qualitative method was used as a research model and document analysis was conducted to explain the data obtained in accordance with the purpose of the study and to access the necessary concepts and relations. As a matter of fact, the document review aims to obtain written and oral materials containing information about the subjects to be researched and to reach results according to the analysis of these data. In the document review, which is among qualitative research methods, the researcher can reach the needed data without observation or interview. Therefore, such researches will contribute to the researcher in terms of saving a certain amount of time and money (Yıldırım \& Şimşek, 2013).

\section{Data Collection Process}

In line with the purpose of the study, initially, the studies conducted on Scratch Programming were accessed for the purpose of collecting the study data. The studies to be examined within the scope of the research were obtained by scanning ERIC, ProQuest and the Higher Education Council (YÖK) National Thesis Center databases. "Scratch" keyword was used to scan the databases. 
Afterward, the "Education / Educational Research" category filter was applied. Finally, a filter application was carried out for studies conducted in English and Turkish. The theses and articles examined were limited to the years between 2009 and 2019. As a consequence of the preliminary examination of the studies, 76 studies, which are appropriate for the purpose and contain necessary and sufficient information, were accessed.

The meta-thematic analysis was also performed by screening qualitative studies to contribute to the internal validity of the research and to provide data diversity. In the literature, meta-thematic analysis can be explained as creating wide-ranging and generalized themes and codes by evaluating the themes and codes in the qualitative studies carried out in a certain subject on common ground (Batd1 \& Batd1, 2015). In this respect, qualitative studies regarding "Scratch programming" were reviewed in the literature. The data obtained from the scan were analyzed using the MAXQDA-11 program.

\section{Data Analysis}

The data collected in the study were analyzed by content analysis method. Content analysis refers to examining the studies conducted within a certain period of time, in a certain field and collecting the data obtained from them under the chosen codes and themes. In content analysis, the data collected under the determined headings are explained and their relations are identified. The collected data are processed, and in-depth information on the subject examined is tried to be obtained and it is tried to come to a conclusion with the data (Yıldırım \& Şimşek, 2013). The expressions in the studies where the related themes and codes were quoted were given in the text in order to support the codes and themes in the current study. For example, 509354-p.79 shows page 79 of the study numbered 509354.

The studies selected for the reliability of the research were examined in detail by two independent evaluators, experts in educational sciences and publish many qualitative studies. The evaluators shared ideas after the coding process and reached common decisions on different opinions.

The compliance values (Cohen Kappa) between the data encoders were calculated for the reliability of the meta-thematic dimension based on document analysis (Viera \& Garrett, 2005). The compliance values calculated for the themes reached this point were found to be positive aspects (.788) and negative aspects (.709) of "Scratch programming". These values' being "a very good level of compliance" revealed that data coding was reliable.

\section{Results}

The findings of 76 studies conducted within the framework of the use of Scratch software in education and reached within the scope of the research were presented under nine categories:

\section{Publication Type and Years of Studies}

Figure 1 shows the distribution of the studies regarding the use of Scratch software in education according to publication type and years of studies. The analyzed studies were gathered under three main headings as "Ph.D. dissertation", "master's thesis" and "article". Besides, the publication years of the studies were determined as 2009-2019.

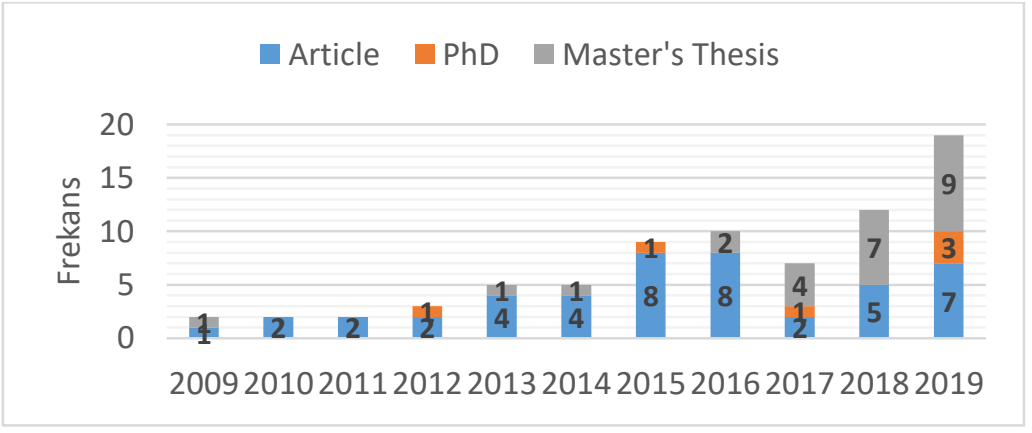

Figure 1. Distribution of Studies by publication type and years 
When the graph in Figure 1 was examined, it was found that six studies were conducted between 2009 and 2011, and three studies were conducted in 2012. An increase was observed in the number of studies conducted in the following years. Besides, it was determined that 45 out of the 76 analyzed studies were articles, and 25 of them were master's theses. Only six of the studies examined were Ph.D. dissertations.

\section{Teaching Stages and Numbers in the Studies}

At which stage and with how many people the studies are conducted have significant effects on the research results. In this context, the teaching level and sample numbers of the studies examined were determined. Figure 2 gives the obtained results.

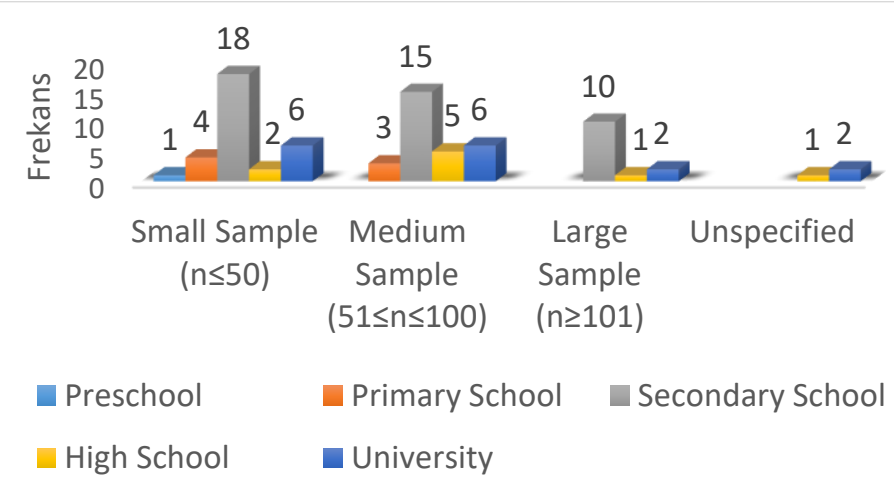

Figure 2. Distribution of the studies by teaching stages and numbers

Considering the graph in Figure 2, it was found that the target groups examined in the studies were mostly at the secondary school level $(n=43)$. Based on this finding, it can be interpreted that the use of Scratch software in education was developed aiming at the 11-15 age group as the target group. On the other hand, the least number of studies is observed to have been performed at preschool $(n=1)$, then primary $(n=7)$ and high school levels $(n=9)$. It was also determined that 29 of the studies were carried out through the medium sample $(51 \leq \mathrm{n} \leq 100)$.

\section{Fields of Education in which the Studies were Conducted}

Within the scope of the research, the disciplines (subject areas) in which this software was used were determined in order to reveal the potential of Scratch software in the educational field and to evaluate the results. The disciplines (course/subject) were separated into four different groups as Science (Biology, Chemistry, Physics, Science Education, Science, and Technology), Social Sciences (Geography, Music, Visual Arts, History, and Language Education), Mathematics, and Computer Science (Computer and Information Technology, Information Technologies and Software, Programming Language, Computer) to investigate the total effect sizes of the meta-analytic studies. As a result of the analysis, two studies were not taken into consideration because the discipline in which the study was performed was not mentioned. The distribution regarding the disciplines in which the studies examined within this scope were examined is presented in Figure 3.

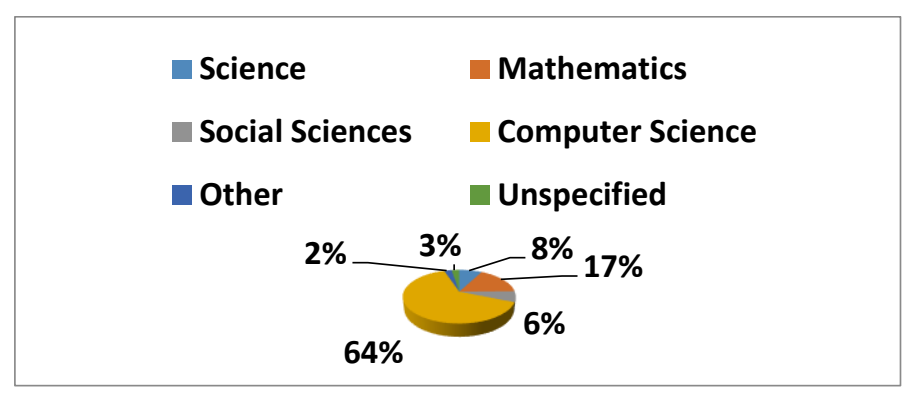

Figure 3. Fields of education in which the studies were conducted 
When the graph in Figure 3 was examined, it was determined that Scratch software was mostly used in the field of Computer Science with 49 (64\%) studies and usually on "Algorithm and the Teaching of Programming". This discipline consists of the teaching of subjects in the fields of mathematics $(17 \%)$ and science $(8 \%)$, respectively. Not many studies were found in the literature regarding the use of the fields of social sciences $(6 \%)$. Since there was a tendency toward an educational field other than the determined ones in the two studies conducted, they were included in the "other" category.

\section{Experimental Application Periods Specified in Studies}

In the study, the application duration of the studies on the use of Scratch software in education was also examined. Knowing the duration of the application of the studies on the subject facilitates the evaluation of the studies and the interpretation of the results. The findings related to the application duration of the studies examined in this context are presented in Figure 4.

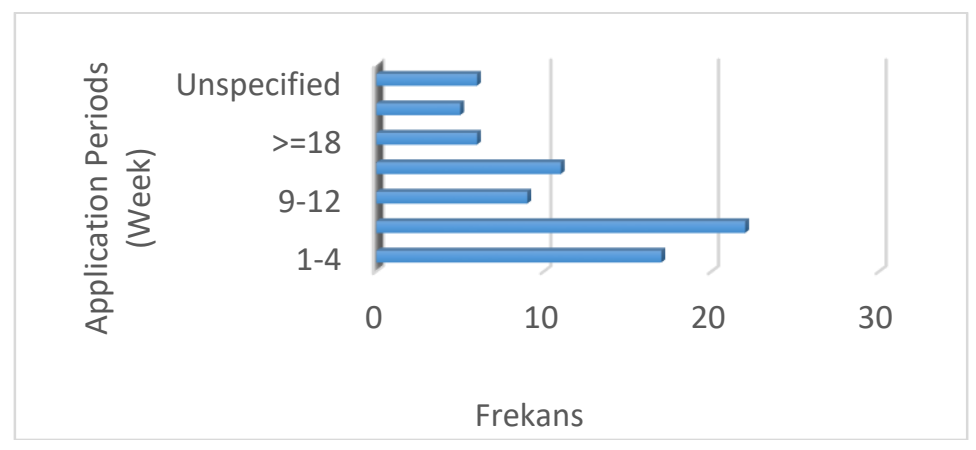

Figure 4. Investigation of studies in terms of application periods

In terms of application periods, 22 studies with a 5-8 week period were identified. Moreover, 17 studies lasted 1-4 weeks, and 11 studies were carried out in 13-17 weeks. Six of the examined studies lasted more than 18 weeks. There was no clear information about the duration of the application of six studies. In addition, five studies were included in the "other" category, because the "hour/session" value was indicated as duration.

\section{Research Methods Used in Studies}

The findings of the research methods used in the studies are given in Figure 5. This study is valuable in terms of identifying the types of studies towards which there is a tendency in the literature and the type of research lacking in the field. While determining the themes related to the research method, three basic methods were classified as quantitative, qualitative and mixed methods. The classification of the researches in terms of methodology was made according to researchers' discourse.

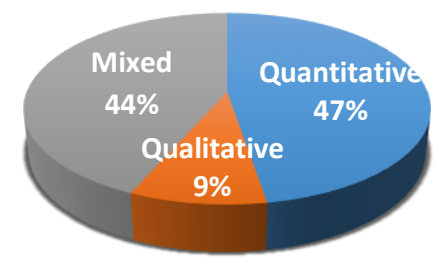

Figure 5. Distribution of the studies by research methods

When the graph in Figure 5 was examined, it was determined that $36(47 \%)$ of the research methods used in the studies were quantitative, $33(44 \%)$ of them were mixed, and seven $(9 \%)$ of them were conducted by the qualitative research method. It draws attention that quantitative and mixed methods were used in close ratios as research methods, but the qualitative method was relatively not preferred. 


\section{Data Collection Tools Used in the Studies}

The distribution of data collection tools used in the studies is presented in Figure 7.

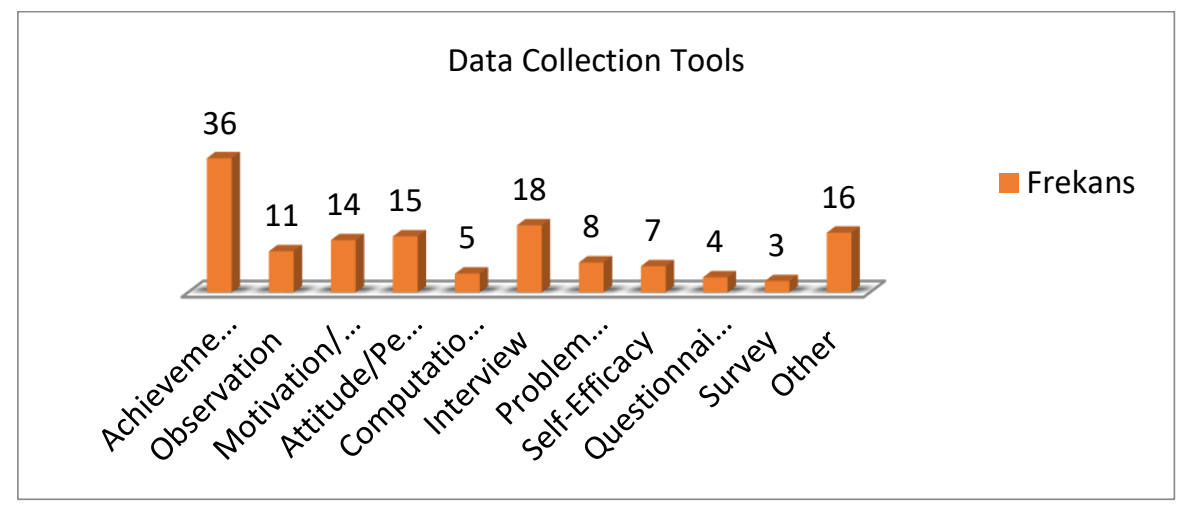

Figure 6. Distribution of Data Collection Tools Used in the Studies

It was determined that most preferred data collection tools are achievement tests $(f=36)$ and interview form $(\mathrm{f}=18)$. In addition, the motivation $(\mathrm{f}=14)$, attitude/perception $(\mathrm{f}=15)$ and observation form $(\mathrm{f}=11)$ are among the frequently preferred data collection tools. It can be said that the reason for these findings to be close to 137 numerically is due to the use of more than one data collection tool at the same time in some studies examined.

\section{Data Analysis Methods Used in the Studies}

The distribution of data analysis methods used in the studies is presented in Table 1.

\section{Table 1}

Distribution of data analysis methods used in the studies

\begin{tabular}{cc}
\hline Category & f \\
\hline Quantitative Descriptive & 17 \\
Frequency/Percentage & 14 \\
Mean/Standard Deviation & 7 \\
Graphical Display & \\
Quantitative Predictive & 34 \\
t-test & 8 \\
ANOVA & 9 \\
Wilcoxon Sign Rank & 4 \\
ANCOVA & 8 \\
Mann Whitney U & 8 \\
Correlation & 3 \\
MANOVA & 1 \\
MANCOVA & 2 \\
Kruskal-Wallis H & 2 \\
Chi-square & 5 \\
Other & \\
Qualitative & 16 \\
Content Analyses & 3 \\
Descriptive Analyses & 2 \\
Other & \\
\hline
\end{tabular}

When Table 1 is analyzed, it was observed that 38 of the studies use descriptive, that 84 use predictive and 21 use qualitative analysis techniques. The frequencies/percentages were observed in 17 studies, while the mean/standard deviation values in 14 of the studies were calculated. In addition, the graphical display method was used in 7 studies. Studies in which predictive analysis was conducted, it was observed that mainly t-test $(\mathrm{f}=34)$, ANOVA $(\mathrm{f}=8)$, Wilcoxon signed-rank $(\mathrm{f}=9)$, 
Mann Whitney $\mathrm{U}(\mathrm{f}=8)$ and correlation tests $(\mathrm{f}=8)$ were used. When qualitative analysis methods are examined, it was observed that content analyses are used in 16 of the studies.

\section{Distribution of Keywords Used in Studies}

Within the scope of the study, the keywords used in the studies were also examined. In the research, we tried to reduce confusion by collecting key expressions that are quite close to each other or synonymous with one keyword. The word cloud of the keywords used in the studies is presented in Figure 7.

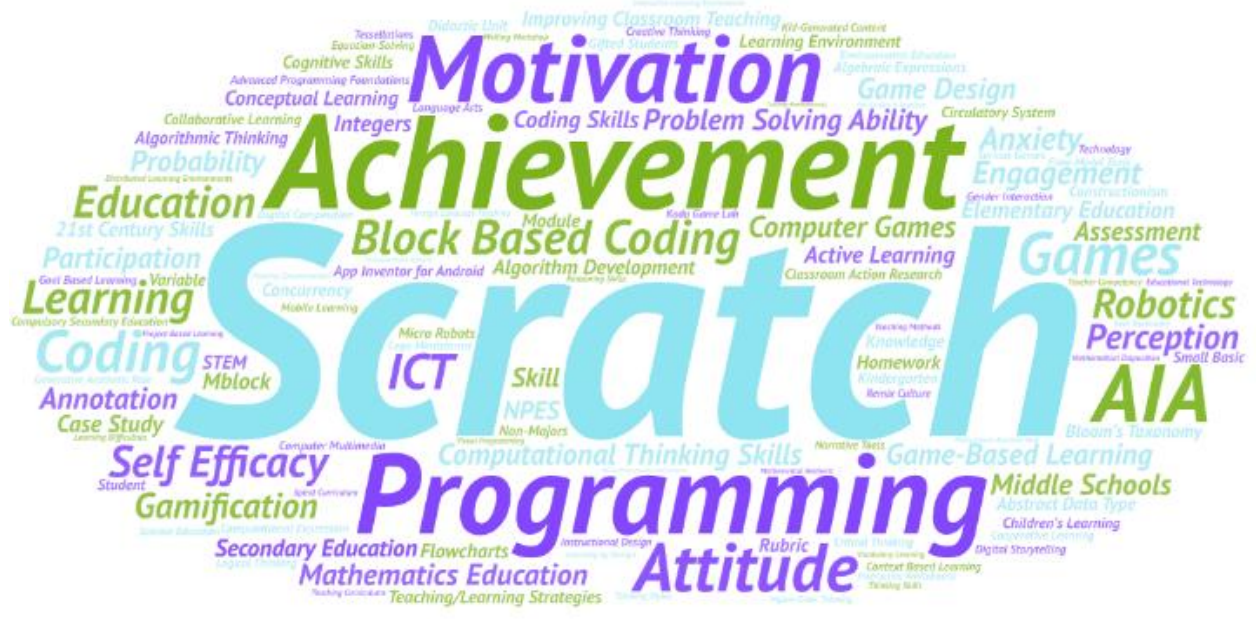

Figure 7. Word cloud for keywords

As a result of the analyses, it was determined that in some of the studies, the keywords remained superficial in reflecting the feature and content of the research, while other studies explained the feature of the research. It was determined that a total of 157 different keywords were included in the studies. When the keywords in the studies were analyzed, it was found that the frequency of using the "Scratch" keyword ( $\mathrm{f}=56$ ) was higher than the other keywords. The most frequently used keywords after the Scratch keyword are "programming" ( $\mathrm{f}=32)$, "achievement" ( $\mathrm{f}=30)$, "motivation" ( $\mathrm{f}=15)$ and "attitude" ( $\mathrm{f}=15) .105$ keywords used in the studies were included only once. In addition, no keywords were used in 8 studies.

\section{Study results}

The studies carried out by using Scratch software in education were collected under three headings as cognitive, affective and aimed at the learning environment, and sub-themes related to these topics were formed. Table 2 shows the obtained findings. The results obtained in the studies are separately shown as "positive results" and "results without a significant difference".

According to the results of the studies regarding cognitive processes, the effect of Scratch software on learning level/success was found to be the most investigated topic with 36 studies. Eight studies were found to be conducted on its impact on problem-solving skills, and seven studies on its effects on self-efficacy. The most investigated effects of Scratch software in the results regarding affective processes were on attitudes $(\mathrm{n}=12)$ and motivation $(\mathrm{n}=13)$ variables. In the results regarding the learning environment, the effects on collaborative work, active participation, and system availability were examined in three separate studies. When the results were generally interpreted, the effects of Scratch software on cognitive and affective processes and learning environment were found to be positive to a large extent. 


\section{Table 2}

Findings regarding the study results

\begin{tabular}{|c|c|c|}
\hline Variables & $\begin{array}{c}\text { Number of Positive } \\
\text { Results }\end{array}$ & $\begin{array}{c}\text { Number of Results without } \\
\text { Significant Difference }\end{array}$ \\
\hline \multicolumn{3}{|l|}{ Results Regarding Cognitive Processes } \\
\hline Learning level / Success & 33 & 3 \\
\hline Problem solving skills & 6 & 2 \\
\hline Self-efficacy & 5 & 2 \\
\hline Information Processing Thinking & 3 & 1 \\
\hline Creativity & 3 & \\
\hline Mathematical thinking skills & 3 & \\
\hline Programming skills & 2 & \\
\hline Computational thinking skills & 4 & 1 \\
\hline Self-regulating skills & 1 & \\
\hline Permanent learning & 3 & \\
\hline Algorithmic thinking skills & 1 & \\
\hline Reading comprehension skills & 1 & \\
\hline Effect on thinking styles & 1 & \\
\hline Designing games & 1 & \\
\hline Reasoning skills & 1 & \\
\hline Critical thinking skills & 1 & \\
\hline \multicolumn{3}{|l|}{ Results Regarding Affective Processes } \\
\hline Attitude & 8 & 4 \\
\hline Motivation & 9 & 4 \\
\hline Interest & 3 & \\
\hline Satisfaction & 1 & \\
\hline Self-Confidence & 1 & \\
\hline Concerns about programming & 1 & \\
\hline \multicolumn{3}{|c|}{ Results on Learning Environment / System } \\
\hline Cooperative Work & 1 & \\
\hline Active Participation & 1 & \\
\hline System Availability & 1 & \\
\hline
\end{tabular}

\section{Thematic Examination Based on Document Analysis}

The themes and codes obtained as a result of the thematic study to complement the obtained data are presented in different models. As a result of detailed examination, thematic data were grouped under different themes in two models. The models highlighting the positive and negative aspects of Scratch software are presented below. 


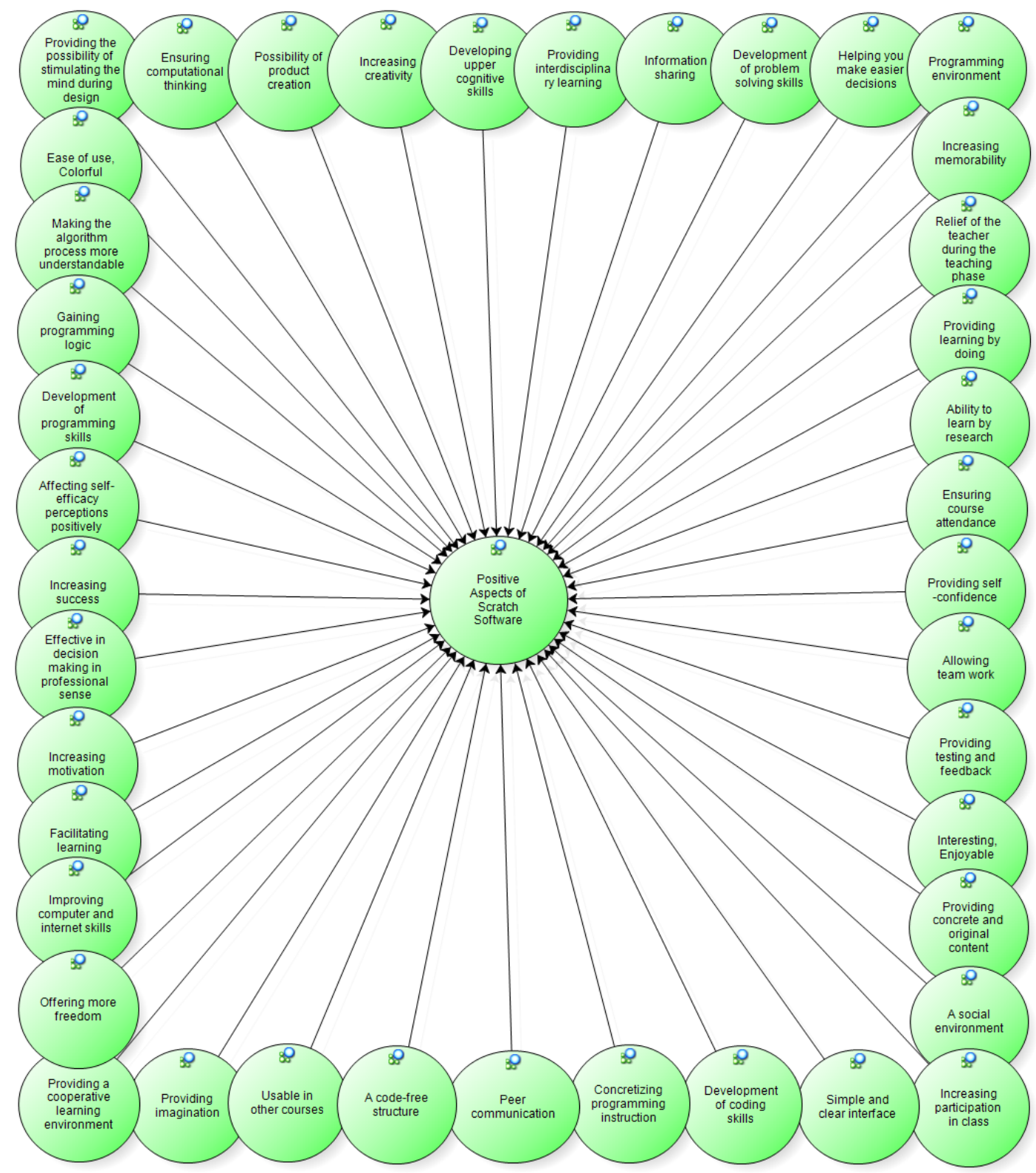

Figure 6. Positive Aspects of Scratch Software

Some of the positive aspects of the Scratch software make the learning fun, more motivating, more understandable, helping to acquire mental skills, such as programming logic, problem-solving, creativity, algorithmic and computational thinking skills, and affecting students' self-confidence, attitudes, and self-efficacy perceptions positively. Within the context of this theme, the expression cited from the study coded 509354-p.79 "Creating animation with Scratch made me dream. I had a game plan in my head. At first, I thought it was simple. But then as I learn to code, I dream of putting different objects in the game. I want to write and play my game with my friends as soon as possible." and the expression cited from the study coded M3-p.5 "As the weeks progressed, I realized how easy programming was" were taken into account as reference sentences and used in the formation of codes.

In addition to the positive aspects of Scratch software, some negative and deficient aspects of it were identified in the studies, and Figure 9 shows the related model. 


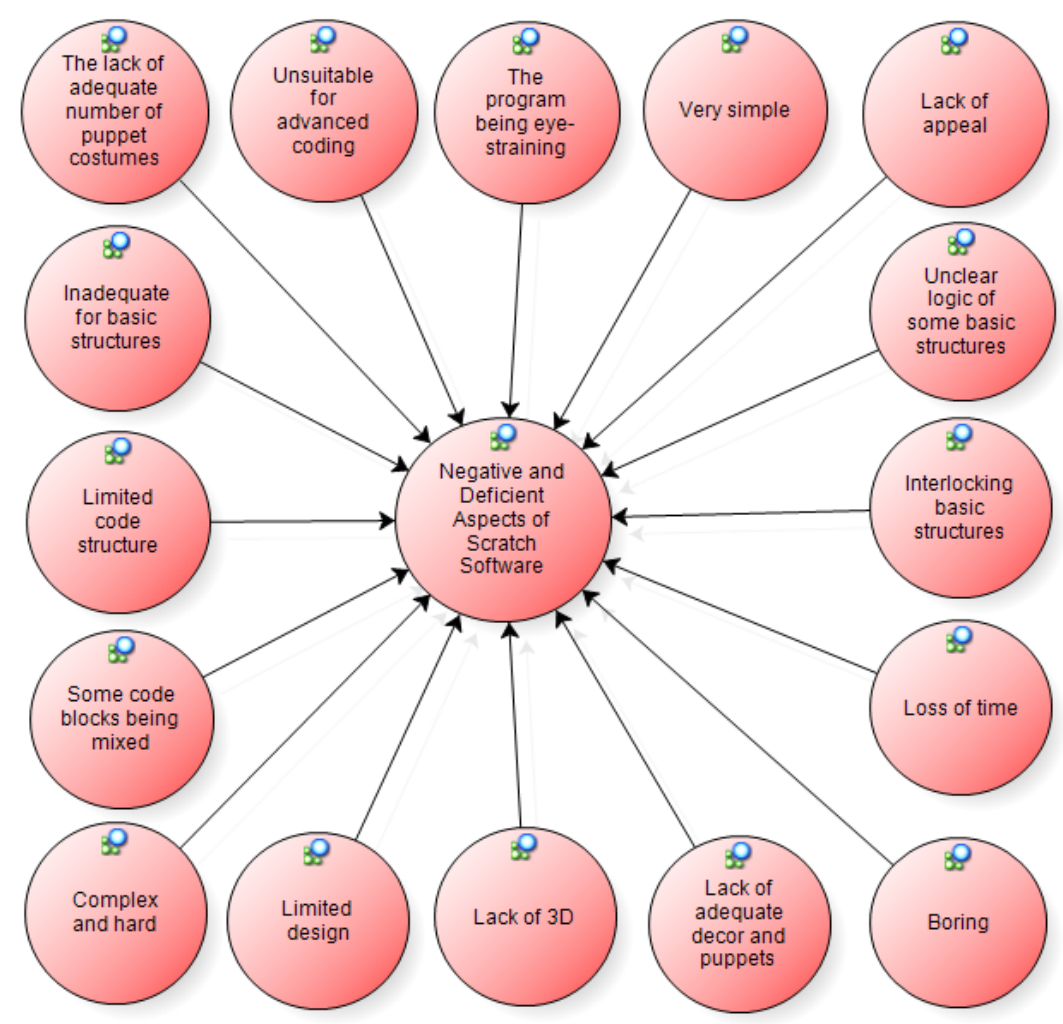

Figure 7. Negative and Deficient Aspects of Scratch Software

Some of the codes related to the negative aspects of Scratch software are as follows: "Insufficient for basic structures, unsuitable for advanced coding, some code blocks are mixed and design is limited". Some of the expressions referenced in the creation of related codes cited from the 395186p.95 coded study are "It may be enough for basic programming, but it may not be enough for advanced programming due to being very simple." or, cited from M1-p.5 coded study "It really did not capture my attention, it is boring, it should have been easier."

\section{Discussion and Conclusion}

This study aimed to examine the scientific studies conducted on the use of Scratch software in education in a comprehensive and holistic manner and to present the current situation. The processes were carried out in line with document analysis to render the subject applicable in the context of current research and to determine its level of effectiveness in terms of different variables. Hence, it can be said that this study will constitute a resource for the literature. In this context, the data of the studies on the subject were examined, and it was determined that the results of many studies overlapped. When the obtained results were analyzed, it was understood that the studies were generally carried out in the middle school level, article publication type, and Computer Science field. On the other hand, it was found that there has been a steady increase in the related publications since 2013, concentrated on the 5-8 week period and realized through the medium sample. It is concluded that the most used data collection tools are achievement tests, interview form, motivation, attitude and observation form. Considering that the quantitative research method was adopted in these studies, it is an expected result that the scale, survey, and test tools, which are among data collection tools, are used more. Furthermore, it was determined that the most used data analysis methods were descriptive statistics and t-test. In the keyword analysis, it was determined that the data related to Scratch and programming are concentrated according to the search criteria. It can be said that the keywords used in the studies are related to the subject. 
In the studies, the effect of Scratch software on various variables was examined, and it was found that the software affected the variables and showed positive results in the general framework. Regarding the results concerning cognitive processes, it may be asserted that scratch software had a significant effect on both learning level/ achievement (Demir, 2015; Erol, 2015; Meerbaum-Salant et al., 2013; Papadakis et al., 2016; Saygıner, 2017; Su et al., 2015; Yıldırım, 2017) and on higher-order thinking skills including problem-solving, computational thinking, creativity, computational thinking and critical thinking (Calao et al., 2015; Oh, Lee, \& Kim, 2013; Yünkül et al., 2017; Yıldırım, 2017). The characteristics that are expressed as not having a mixed code structure, easy to learn, students' have the chance to learn while having fun and providing active participation in the teaching process can be listed as the reasons explaining the increase in students' success. In the results regarding the affective processes, it can be stated that Scratch software had a significant effect on students' attitudes and motivations thanks to its being fun, interesting, simple and its understandable interface and multimedia support (Ke, 2014; Ortiz-Colón \& Maroto Romo, 2016; Saygıner, 2017; Saez-Lopez, Roman-Gonzalez \& Vazquez-Cano, 2016). It can also be added that it provides a collaborative work environment (Papatğa, 2016; Taylor, Harlow \& Forret, 2010), active participation (Saez-Lopez, Roman-Gonzalez \& Vazquez-Cano, 2016)) and is not only used in programming courses but also in different courses (Sayginer, 2017).

Within the scope of the study, meta-thematic analyses were also conducted, and positive and negative aspects of the use of Scratch software in education were determined, and various themes and codes related to it were created. Some of the positive aspects of Scratch software are that teaching is materialized by being freed from an abstract and complex structure (Demir, 2015; Ersoy, Madran \& Gülbahar, 2011), that it positively affects students' self-efficacy perceptions (Ihmaid, 2017; Psycharis \& Kallia, 2017; Yükseltürk \& Altık, 2016a) and it develops programming skills (Oluk \& Korkmaz, 2016; Ruf, Mühling \& Hubwieser, 2014; Yıldırım, 2017). Moreover, it can be stated that coding with Scratch facilitates students' understanding of the basics of programming, excites them and thereby increases their motivation for computer programming, enables them to trust themselves and prevents negative situations such as losing interest, not making efforts and giving up on the course (Calder, 2010; Ersoy et al., 2011; Yükseltürk \& Altıok, 2016b). Furthermore, Scratch software provides users with an easy, practical and entertaining programming experience, which can be effective in helping users gain 21 st-century skills, such as creativity, problem-solving, algorithmic, mathematical and computational thinking at an early age (Calder, 2010; Kobsiripat, 2015; Oh, Lee \& Kim, 2013; Taylor, Harlow \& Forret, 2010; Yıldırım, 2017; Yünkül et al., 2017). In addition to all these features, Scratch software makes the process of algorithms more understandable, enables students to create more concrete and original content, and renders this process more interesting (Erol, 2015; Utting et al., 2010).

It should be noted that Scratch software has some negative and deficient aspects along with its contributions to education. In the studies, Scratch's insufficiency for some basic structures, the interlocking of the structures and the failure to understand the logic (Erol, 2015) are expressed as the limitations of the software. In addition, the complexity, difficulty, and dullness of its algorithm, that the program is eye-straining and the loss of time it causes in setting the stage (Gezgin et al., 2017; Quan, 2015) is expressed as the negative aspects of the software. Besides, it was concluded that the fact that puppets were not 3 dimensional and that the number of decors, puppets, and costumes was limited the student at the animation stage (Vatansever, 2018).

\section{Suggestions}

This study is limited to scientific researches and search terms for the use of Scratch software in education between 2009 and 2019. In addition, this study is limited to full-text access of masters, doctoral thesis and articles published in refereed journals in English and Turkish languages. It does not include studies conducted in different languages and other types of publications (such as book chapters, papers, book reviews, and opinion essays). The findings and results obtained can only be generalized only when evaluated within the same context. Therefore, different research findings can be obtained by making wider and more comprehensive searches. 
It is considered that the findings and results obtained will constitute an important reference base for researchers and educators and contribute to the field. Based on the results of the studies examined, the suggestions of the research are given below.

Running a content analysis on the use of Scratch software in education for certain years is considered important by the researcher for the follow-up of this subject. Therefore, similar researches can be repeated at certain periods and the development in the field can be followed. This type of research on the subject of the research can reveal the existing trends, new trends and possible research topics in the study fields.

In the evaluation made by years, it is observed that the number of studies on the subject is increasing day by day. This increase in numbers is mostly seen in articles and master's theses. It can be suggested to increase the number of doctoral theses which can be considered more qualified in scientific terms and to encourage doctoral students to work in this field.

As a result of the research, it was determined that the target population examined in the studies was mostly the middle school level and the sample selection was mostly based on small and medium samples. Accordingly, in the studies to be carried out, selection of samples suitable for the study design and selection of all stakeholders on the subject as the sample group can be an important data source for the quality of publications, areas of application, policy developers, the literature and future studies.

Based on the data obtained as a result of the content analysis, it is seen that the publications are mostly concentrated in the field of Computer sciences. Accordingly, making academic publications in different fields can make a significant contribution in terms of being inclusive of education fields.

Researchers can focus on qualitative studies as well as quantitative research. In addition, in the new studies to be conducted, diversification of data and diversity of data collection tools are suggested in order to obtain more reliable data and add depth to the research.

It was observed that there is a variety of research subjects that are revealed as a result of the analysis, though little in number. It is recommended that the studies on the subject should be diversified and their numbers should be increased, and that other variables and subjects that have not been investigated are investigated very little should be researched and studied.

In conclusion, in light of these suggestions, it is considered that examining the studies conducted on the use of Scratch software in education in the specified contexts will contribute to the literature, will reveal the differences and similarities in the studies and will shed light on the studies to be conducted.

\section{References}

Adams, J.C. (2010). Scratching middle schoolers' creative itch. In Proceding of SIGCSE Technical Symposium on Computer Science Education, (pp.356-360), Milwaukee, Wisconsin, USA.

Anastasiadou, S.D., \& Karakos, A.S. (2011). The beliefs of electrical and computer engineering students' regarding computer programming. The International Journal of Technology, Knowledge and Society, 7(1), 37-51.

Armoni, M., Meerbaum-Salant, O., \& Ben-Ari, M. (2015). From scratch to "real" programming. ACM Transactions on Computing Education (TOCE), 14(4), 25:1-15.

Batd1, V., \& Batd1, H. (2015). Effect of creative drama on academic achievement: A meta-analytic and thematic analysis. Educational Sciences: Theory \& Practice, 15(6), 1459-1470.

Brennan, K., \& Resnick, M. (2013). Stories from the scratch community: connecting with ideas, interests, and people. In Proceeding of the 44th ACM Technical Symposium on Computer Science Education (pp. 463-464). ACM.

Brown, Q., Mongan, W., Kusic, D., Garbarine, E., Fromm, E., \& Fontecchio, A. (2008). Computer aided instruction as a vehicle for problem solving: Scratch programming environment in the middle years classroom. J. Lohmann (Ed.), ASEE Annual Conference \& Exposition (pp. 92859300). Washington DC: American Society for Engineering Education. 
Calao, L.A., Moreno-Le'on J., Correa H. E., \& Robles, G. (2015). Developing mathematical thinking with scratch an experiment with 6th grade students. Design for Teaching and Learning in a Networked World, 10th European Conference on Technology Enhanced Learning, 9307, 17-27.

Calder, N. (2010). Using Scratch: An integrated problem-solving approach to mathematical thinking. Australian Primary Mathematics Classroom, 15(4), 9-14.

Demir, F. (2015). Programlama öğretiminde eğitsel programlama dilinin farkl kullanımlarının programlama başarisl ve kaygisina etkisi [The effect of different usage of the educational programming language in programming education on the programming anxiety and achievement]. (Unpublished Doctoral Disseration). Atatürk University, Erzurum.

Dinçer, A. (2018). 6.Sinuf öğrencilerine Scratch ve Kodu Game Lab programlama dillerinin ögretiminde öğrencilerin tutum, öz yeterlilik ve akademik başarılarının karşılaştırllması [The comparison of 6th grade students' in terms of attitudes, self-efficacy and academic achievement on teaching of scratch and kodu game lab 'programming languages]. (Unpublished Master Thesis). Dokuz Eylül University, İzmir.

Erol, O. (2015). Scratch ile programlama ögrretiminin bilişsim teknolojileri ögretmen adaylarının motivasyon ve başarlarina etkisi. [The effects of teaching programming with Scratch on preservice information technology teachers' motivation and achievement]. (Unpublished Doctoral Dissertation). Anadolu University, Eskişehir.

Ersoy, H., Madran, R.O., \& Gülbahar, Y. (2011). Programlama dilleri öğretimine bir model önerisi: Robot programlama. In Akademik Bilişim Konferansı, Inonu University, Malatya.

Fesakis, G., \& Serafeim, K. (2009). Influence of the familiarization with "Scratch" on future teachers' opinions and attitudes about programming and ICT in education. In Proceedings of the 14th Annual ACM SIGCSE Conference on Innovation and Technology in Computer Science Education, Paris, France.

Genç, Z., \& Karakuş, S. (2011). Tasarımla öğrenme: Eğitsel bilgisayar oyunları tasarımında Scratch kullanımı [Learning Through Design: Using Scratch in Instructional Computer Games Design]. In 5th International Computer \& Instructional Technologies Symposium (ICITS), Firat University, Elazığ, Turkey.

Gezgin D.M., Özcan S., Ergün K., Köse Ö., \& Emir, N., (2017). Bilgisayar programlama eğitiminde Scratch programı kullanımına ilişkin lise öğrencilerinin görüşleri [High school students' opinions regarding the Scratch program use in computer programming course]. In 2nd International Scientific Researches Congress on Humanities and Social Sciences (IBAD-2017), İstanbul, Turkey.

Ihmaid, (2017). The effectiveness of using Scratch applications in developing sixth graders' English vocabulary, its retention, and self-efficacy. (Unpublished Master Thesis), The Islamic University, Gaza, Palestinian.

Ke, F. (2014). An implementation of design-based learning through creating educational computer games: A case study on mathematics learning during design and computing. Computers \& Education, 73, 26-39.

Kinnunen, P., \& Malmi, L. (2008). CS minors in a CS1 course. In Proceeding of the Fourth International Workshop on Computing Education Research, ICER (s.79 -90). New York, USA.

Kobsiripat, W. (2015). Effects of the media to promote the scratch programming capabilities creativity of elementary school students. Procedia-Social and Behavioral Sciences, 174, 227-232.

Lahtinen, E., Ala-Mutka, K., \& Järvinen, H. (2005). A study of the difficulties of novice programmers. ACM SIGCSE Bulletin, 37(3), 14-18.

Lopez, J.M., Gonzalez, M.R., \& Cano, E.V. (2016). Visual programming languages integrated across the curriculum in elementary school: A two year case study using "Scratch" in five schools. Computers \& Educations, 97, 129-141.

Maloney, J., Resnick, M., Rusk, N., Silverman, B., \& Eastmond, E. (2010). The Scratch programming language and environment. Trans. Comput. Educ., 10(4), 1-15. 
Meerbaum-Salant, O., Armoni, M., \& Ben-Ari, M. (2013). Learning computer science concepts with scratch. Computer Science Education, 23(3), 239-264.

Nam, D., Kim, Y., \& Lee, T. (2010). The effects of scaffolding-based courseware for the scratch programming learning on student problem solving skill. In Proceedings of the 18th International Conference on Computers in Education. Putrajaya, Malaysia.

Oh J., Lee J., \& Kim J. (2013). Development and application of STEAM based education program using Scratch: Focus on 6th graders' science in elementary school. In: Park J., Ng JY., Jeong HY., Waluyo B. (eds) Multimedia and Ubiquitous Engineering. Lecture Notes in Electrical Engineering, 240, 493-501. doi.org/10.1007/978-94-007-6738-6_60

Oluk, A., \& Korkmaz, Ö. (2016). Comparing students' Scratch skills with their computational thinking skills in terms of different variables. I.J. Modern Education and Computer Science, 11, $1-7$.

Ortiz-Colon, A.M., \& Romo, J.L.M. (2016). Teaching with Scratch in compulsory secondary education. International Journal of Emerging Technologies in Learning (iJET), 11(02), 67-70.

Papadakis, S., Kalogiannakis, M., Zaranis, N., \& Orfanakis,V. (2016). Using Scratch and App Inventor for teaching introductory programming in secondary education. A case study. International Journal of Technology Enhanced Learning, 8(3/4), 217-233. doi:10.1504/IJTEL.2016.10001505.

Papatğa, E. (2016). Okuduğunu anlama becerilerinin SCRATCH programı aracılı̆̆lyla gelişstirilmesi [Developing reading comprehension skills through SCRATCH program]. (Unpublished Doctoral Dissertation), Anadolu University, Eskişehir.

Psycharis, S., \& Kallia, M. (2017). The effects of computer programming on high school students' reasoning skills and mathematical self-efficacy and problem solving. Instructional Science, 45(5), 583-602.

Quan, C.G. (2015). Student teachers evaluating and assessing SCRATCH in the Applied Linguistics classroom. Procedia-Social and Behavioral Sciences, 174, 1450-1456.

Ramadhan, H.A. (2000). Programming by discovery. Journal of Computer Assisted Learning, 16, 8393.

Resnick, M., Maloney, J., Monroy-Hernández, A., Rusk, N., Eastmond, E., Brennan, K., Millner, A., Rosenbaum, E., Silver, J., Silverman, B., \& Kafai, Y. (2009). Scratch: Programming for all. Communications of the ACM, 52(11), 60-67.

Ruf, A., Muhling, A., \& Hubwieser, P. (2014). Scratch vs. Karel: impact on learning outcomes and motivation. In Proceedings of the 9th Workshop in Primary and Secondary Computing Education. Berlin, Germany.

Sáez-López, J.M., Román-González, M., \& Vázquez-Cano, E. (2016). Visual programming languages integrated across the curriculum in elementary school: A two year case study using "Scratch" in five schools. Computers \& Education, 97, 129-141.

Saygıner, Ş., (2017). Blok tabanl görsel ve metin tabanl programlama öğretimlerinin erişsi, mantıksal düşünme ve motivasyona etkileri [Effects of block-based visual and text-based programming instruction on achievement, logical thinking and motivation]. (Unpublished Master Thesis), Hacettepe University, Ankara.

Scratch (2019). Scratch about. [https://scratch.mit.edu/about]

Şimşek, E., (2018). Programlama ögretiminde robotik ve Scratch uygulamalarının öğrencilerin bilgi işlemsel düşünme becerileri ve akademik başarllarına etkisi [The effect of robotics and scratch applications on computational thinking skills and academic achievement in programming instruction]. (Unpublished Master Thesis), Ondokuz Mayis University, Samsun.

Smith, B.J. (2009). Conceptual graphs as a visual programming language for teaching programming. In 2009 IEEE Symposium on Visual Languages and Human-Centric Computing (VL/HCC) (pp. 258-259). IEEE. 
Su, A.Y., Huang, C.S., Yang, S.J., Ding, T.J., \& Hsieh, Y.Z. (2015). Effects of Annotations and homework on learning achievement: An empirical study of scratch programming Pedagogy. Educational Technology \& Society, 18(4), 331-343.

Taylor, M., Harlow, A., \& Forret, M. (2010). Using a computer programming environment and an interactive whiteboard to investigate some mathematical thinking. Procedia-Social and Behavioral Sciences, 8, 561-570.

Utting, I., Cooper, S., Kölling, M., Maloney, J., \& Resnick, M. (2010). Alice, greenfoot, and scratch-a discussion. ACM Transactions on Computing Education (TOCE), 10(4), 17:1-11.

Vatansever, Ö. (2018). Scratch ile programlama ögretiminin ortaokul 5. ve 6. sinif öğrencilerinin problem çözme becerileri üzerindeki etkisinin incelenmesi [Examining The effects of using Scratch programming on 5th and 6th graders' problem solving skills]. (Unpublished Master Thesis), Uludağ University, Bursa.

Viera, A.J., \& Garrett, J.M. (2005). Understanding interobserver agreement: The kappa statistic. Family Medicine, 37(5), 360-363.

Yıldırım, A., \& Şimşek, H. (2013). Sosyal bilimlerde nitel araştırma yöntemleri. Seckin Publishing, Ankara.

Yıldırım, E. (2017). Scratch programlama dili eğitimine yönelik bir mobil uygulamanın gelişstirilmesi [Development of a mobile application oriented for scratch programming education]. (Unpublished Master Thesis), Çanakkale Onsekiz Mart University, Çanakkale.

Yükseltürk, E., \& Altık, S. (2016). Investigation of pre-service information technology teachers' game projects prepared with Scratch. SDU International Journal of Educational Studies, 3(1), 59-66.

Yükseltürk, E., \& Altıok, S. (2016). Pre-service information technology teachers` perceptions about using Scratch tool in teaching programming. Mersin University Journal of the Faculty of Education, 12(1), 39-52.

Yünkül, E., Durak, G., Çankaya, S., \& Misırlı, Z. A. (2017). The effects of Scratch software on students' computational thinking skills. Necatibey Faculty of Education, Electronic Journal of Science and Mathematics Education, 11(2), 502-517. 
